\begin{tabular}{|c|c|c|}
\hline \multirow{3}{*}{$\begin{array}{r}\text { Case Reports in } \\
\text { Gastroenterology }\end{array}$} & \multirow{2}{*}{\multicolumn{2}{|c|}{ Case Rep Gastroenterol 2016;10:755-759 }} \\
\hline & & \\
\hline & $\begin{array}{l}\text { DOI: 10.1159/000452199 } \\
\text { Publisned oninne: December 13, } 2016\end{array}$ & $\begin{array}{l}\text { (C) } 2016 \text { The Author(s) } \\
\text { Published by S. Karger AG, Basel } \\
\text { www.karger.com/crg }\end{array}$ \\
\hline & \multicolumn{2}{|c|}{$\begin{array}{l}\text { This article is licensed under the Creative Commons Attribution-NonCommercial } 4.0 \\
\text { International License (CC BY-NC) (http://www.karger.com/Services/OpenAccessLicense). } \\
\text { Usage and distribution for commercial purposes requires written permission. }\end{array}$} \\
\hline
\end{tabular}

\title{
A Rare Cause of Dysphagia to Remember: Calcific Tendinitis of the Longus Colli Muscle
}

\author{
Dominic M. Colella Fiorela Calderón Sandoval David W. Powers \\ Nimal Patel Javier Sobrado \\ Department of Gastroenterology, Larkin Hospital, Nova Southeastern University, \\ South Miami, FL, USA
}

\section{Keywords}

Longus colli muscle $\cdot$ Tendinitis · Dysphagia · Odynophagia · Torticollis · Leukocytosis

\begin{abstract}
Longus colli tendinitis (LCT) is an acute inflammatory condition with symptoms typically consisting of acute neck pain and stiffness with or without dysphagia. Once more severe etiologies for these symptoms are ruled out, this self-limiting condition usually resolves spontaneously with nonsteroidal anti-inflammatory drugs and corticosteroids. We present a case of LCT that presented as acute neck pain, dysphagia, and odynophagia that rapidly resolved once diagnosed and treated with anti-inflammatory agents. Though exceedingly rare, LCT must be considered in the differential diagnosis of acute neck pain, dysphagia, and odynophagia when more common etiologies do not correlate with the clinical presentation.
\end{abstract}

(C) 2016 The Author(s)

Published by S. Karger AG, Basel

\section{Introduction}

Little is known about longus colli tendinitis (LCT), a rare inflammatory condition believed to be caused by the deposition of calcium hydroxyapatite crystals in the longus colli muscle. Also known as calcific tendinitis of the longus colli muscle or retropharyngeal tendi- 
nitis, LCT is characterized by the acute presentation of severe neck pain, dysphagia, torticollis, and/or a painful restriction of neck movement. Its presentation may resemble more serious conditions requiring immediate treatment, such as meningitis, retropharyngeal abscess, foreign body aspiration, or traumatic injury. Patients also typically present with mild leukocytosis, which should prompt investigation to first rule out infectious etiologies. Characteristic radiographic findings of the neck include calcifications in the superior longus colli muscle tendons at the level of $\mathrm{C} 1$ or $\mathrm{C} 2$, which confirm the diagnosis. The incidence of LCT has been reported to be 1.31 per 100,000 person-years but may actually be higher due to the belief that the disorder is underdiagnosed. Therefore, we would like to make practitioners aware that LCT is an important etiology for neck pain that must always be included in the differential diagnosis for acute neck symptomatology.

\section{Case Report}

A 44-year-old female patient with a history of gastric ulcers, gastritis, gastric polyps, Schatzki ring, and hiatal hernia presented with the complaint of progressive dysphagia to solid foods. This dysphagia first developed after an incident of food aspiration 4 weeks prior to presentation. Three weeks after this event, she experienced persistent odynophagia with left-sided occipital headaches and neck pain radiating to the left ear and mastoid process. Physical examination was remarkable for decreased neck range of motion with flexion and extension and bilateral neck soft tissue tenderness to palpation. Laboratory studies revealed only a white blood cell count of 11.88. After an infectious etiology had been ruled out, an upper gastrointestinal series with barium swallow confirmed the patient's known Schatzki ring and hiatal hernia. A CT scan, MRI, and MRA of the brain were negative for abnormalities; however, a CT scan of her neck was positive for calcified longus colli tendons just interior to the anterior ring of her C1 vertebrae (Fig. 1, Fig. 2). The patient underwent a trial of oral nonsteroidal anti-inflammatory drugs (NSAIDs) and corticosteroids that quickly improved her dysphagia and odynophagia, which soon also resolved.

\section{Discussion}

This case presentation emphasizes the importance of having a vast differential diagnosis for relatively common complaints, such as neck pain and dysphagia. It is important to carefully contemplate these differentials in order to not misdiagnose less common yet benign etiologies for these complaints, such as LCT. The longus colli muscle is a prevertebral muscle of the anterior neck that consists of a superior oblique, inferior oblique, and vertical portion. It is innervated by the anterior rami of $\mathrm{C} 2-\mathrm{C} 6$ from the cervical plexus. The longus colli muscle assists in cervical flexion and ipsilateral side-bending and rotation [1]. The mean annual crude incidence of LCT was found to be 0.50 cases per 100,000 person-years, with a standardized incidence of 1.31 for the age-matched population [2]. It most commonly affects both males and females between the ages of 30 and 60 years, as seen in our 44-year-old female [3].

The pathophysiology behind LCT is explained by a reactive inflammatory process induced by calcium hydroxyapatite crystal deposition on the longus colli tendon [4]. These calcifications, which are usually present in the superior oblique portion of the longus colli muscle at the $\mathrm{C} 1-\mathrm{C} 2$ levels, are the cause of symptom development [5]. The most common 
presenting symptoms are neck pain (94\%), limited neck range of motion (45\%), odynophagia (45\%), neck stiffness (42\%), dysphagia (27\%), sore throat (17\%), and neck spasm (11\%) [6]. Our patient displayed all of these signs and symptoms except for sore throat and neck spasm. Laboratory findings typically include mildly elevated white blood cell count, erythrocyte sedimentation rate, and C-reactive protein, but this case featured only an isolated white blood cell count of 11.88. Useful imaging studies include plain radiography, CT, and MRI. CT is the gold standard for diagnosing LCT, as it is readily available and can detect both prevertebral edema and calcium hydroxyapatite crystal deposition at the longus colli tendon [4, 7]. MRI can show prevertebral edema and corresponding effusion, but it is difficult to recognize calcific deposits $[4,7,8]$. This patient demonstrated longus colli calcifications in the anterior ring of the $\mathrm{C} 1$ vertebrae found on CT.

The differential diagnosis between LCT and other diseases showing similar clinical features includes meningitis, retropharyngeal abscess, neoplasm, cervical disc herniation, and traumatic fracture dislocation. The most important mimickers of LCT are meningitis and retropharyngeal abscess [4, 7]. It is critical to thoroughly work up the case in order to make a correct initial diagnosis and avoid unnecessary interventions. Unlike meningitis and retropharyngeal abscesses, which are often associated with high morbidity, antibiotics use, and surgical intervention, LCT is a benign, self-limiting disease. NSAIDs are the first-line treatment for LCT and often alleviate symptoms, but in severe cases, corticosteroids and opioids may be necessary to abate acute symptom exacerbations $[4,6,8]$. Immobilization with a soft cervical collar is another useful method to avoid symptom aggravation [4]. Symptoms typically resolve within a few days of treatment initiation, and the patient often becomes symptom-free after 1-3 weeks $[6,9]$. Our patient required both oral NSAIDs and corticosteroids, which quickly improved her dysphagia and odynophagia within 1 day of treatment initiation. She became symptom-free within 3 days.

LCT is a rare, unusual clinical entity believed to be underdiagnosed due to its often nonspecific presentation. Increased awareness of the disease and its progressive presentation would perhaps yield more timely identification to avoid diagnostic errors and unnecessary patient and physician anxiety. Appropriate treatment can then be initiated to avoid misdirected invasive measures. Therefore, it is imperative that practitioners be aware of LCT as an important etiology for various presentations of unexplainable neck pain, dysphagia, and odynophagia.

\section{Author Contributions}

Dominic M. Colella and Fiorela Calderón Sandoval wrote the manuscript, David W. Powers and Nimal Patel revised the manuscript, and Javier Sobrado critically revised the manuscript and is the guarantor.

\section{Statement of Ethics}

Informed consent was obtained for publication of this case report. 


\section{Case Reports in Gastroenterology}

\begin{tabular}{l|l}
\hline Case Rep Gastroenterol 2016;10:755-759 \\
\hline DOI: 10.1159/000452199 & $\begin{array}{l}\text { C 2016 The Author(s). Published by S. Karger AG, Basel } \\
\text { www.karger.com/crg }\end{array}$ \\
\hline
\end{tabular}

Colella et al:: A Rare Cause of Dysphagia to Remember: Calcific Tendinitis of the Longus Colli Muscle

\section{Disclosure Statement}

The authors have no financial disclosure to report.

\section{References}

1 Drake RL, Vogl W, Mitchell A, Gray H: Gray's Anatomy for Students. Philadelphia, PA, Elsevier/Churchill Livingstone, 2005.

2 Horowitz G, Ben-Ari 0, Brenner A, Fliss DM, Wasserzug 0: Incidence of retropharyngeal calcific tendinitis (longus colli tendinitis) in the general population. Otolaryngol Head Neck Surg 2013;148: 955-958.

-3 Kaplan M, Eavey R: Calcific tendinitis of the longus colli muscle. Ann Otol Rhinol Laryngol 1984;93: 215-219.

-4 Ring D, Vaccaro AR, Scuderi G, Pathria MN, Garfin SR: Acute calcific retropharyngeal tendinitis. Clinical presentation and pathological characterization. J Bone Joint Surg Am 1994;76:1636-1642.

$\checkmark 5$ Eastwood J, Hudgins P, Malone D: Retropharyngeal effusion in acute calcific prevertebral tendinitis: diagnosis with CT and MR imaging. Am J Neuroradiol 1998;19:1789-1792.

-6 Park R, Halpert D, Baer A, Kunar D, Holt P: Retropharyngeal calcific tendinitis: case report and review of the literature. Semin Arthritis Rheum 2010;39:504-509.

7 Omezzine S, Hafsa C, Lahmar I, Driss N, Hamza H: Calcific tendinitis of the longus colli: diagnosis by CT. Joint Bone Spine 2008;75:90-91.

$\checkmark 8$ Offiah C, Hall E: Acute calcific tendinitis of the longus colli muscle: spectrum of CT appearances and anatomical correlation. Br J Radiol 2009;82:117-121.

9 Chung T, Rebello R, Gooden E: Retropharyngeal calcific tendinitis: case report and review of literature. Emerg Radiol 2005;11:375-380.

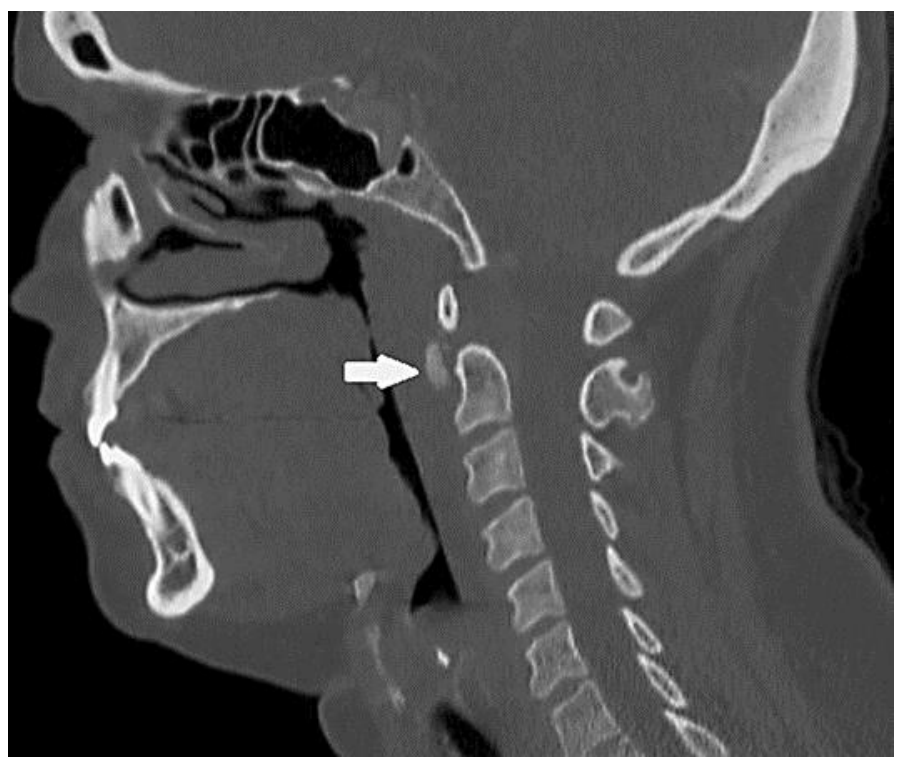

Fig. 1. Sagittal CT of the neck demonstrated longus colli calcifications (arrow) just inferior to the anterior ring of the $\mathrm{C} 1$ vertebrae. 


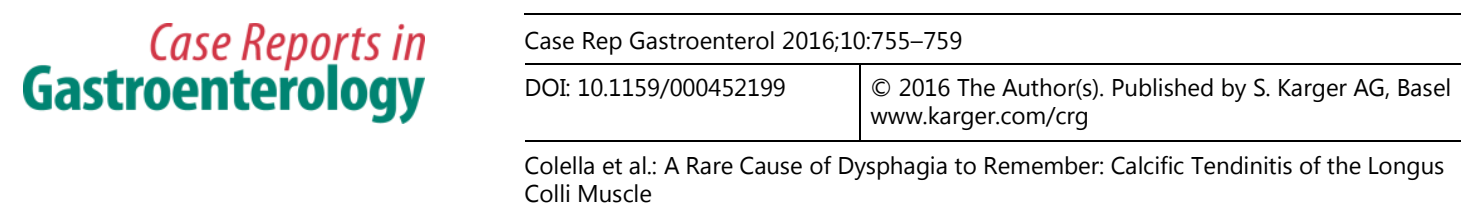

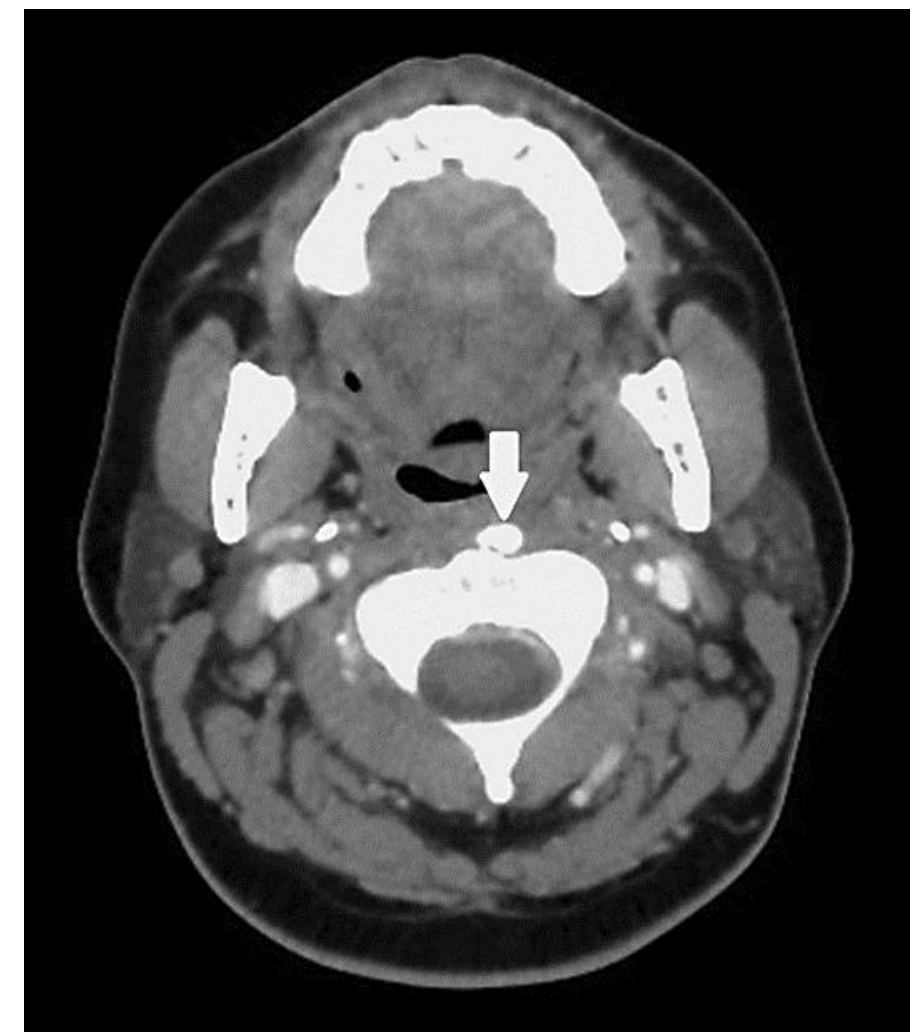

Fig. 2. Axial CT of the neck demonstrated longus colli calcifications (arrow) just inferior to the anterior ring of the $\mathrm{C} 1$ vertebrae. 